\title{
ANALISIS PENGARUH HARGA KOMODITAS DAN PASAR MODAL DUNIA TERHADAP IHSG
}

\author{
Dian Surya Sampurna ${ }^{1}$, Joko Bagio Santoso ${ }^{2}$ \\ Sekolah Tinggi Ilmu Ekonomi Indonesia, Jakarta \\ Jl. Kayu Jati Raya No. 11, Rawamangun, Jakarta \\ dian_surya_sampurna@stei.ac.id ${ }^{1}, \underline{\text { santoso_jb@yahoo.com }}{ }^{2}$
}

\begin{abstract}
Abstrak - Tujuan dari penelitian ini yaitu untuk mengetahui pengaruh indikator ekonomi global dan beberapa indeks saham dunia terhadap IHSG. Metode analisis yang digunakan dalam penelitian ini adalah metode analisis regresi linear berganda. Salah satu syarat untuk melakukan uji analisis regresi linier berganda perlu dilakukan uji asumsi klasik. Hal ini diperlukan agar persamaan regresi yang dihasilkan bersifat BLUE (Best, Linear, Unbiased, Estimator). Selain itu untuk menilai goodness of fit suatu model dilakukan uji $F$, uji $t$, dan koefisien determinasi. Penelitian ini menggunakan data bulanan dari Januari 2010 sampai Januari 2016 untuk setiap variabel. Hasil dari penelitian ini menunjukkan bahwa variabel Indeks Nikkei 225 berpengaruh negatif terhadap IHSG. Sementara variabel Harga Minyak Dunia, Harga Emas Dunia, dan Indeks Dow Jones berpengaruh positif terhadap IHSG. Selain itu diperoleh bahwa nilai adjusted $R^{2}$ adalah 88,4\%. Hal ini berarti $88,4 \%$ pergerakan IHSG dapat diprediksi dari pergerakan keempat variabel independen tersebut.
\end{abstract}

Keywords : IHSG, pasar modal dunia, ekonomi makro

\begin{abstract}
The purpose of this study is to determine the effect of global economic indicators and world stock indexs on JCI. The method of analysis used in this research is multiple linear regression analysis method. One of the requirements to perform multiple linear regression analysis test is to test the classical assumption. It is necessary that the resulting regression equation be BLUE (Best, Linear, Unbiased, Estimator). In addition to assessing the goodness of fit a model performed $F$ test, $t$ test, and coefficient of determination. This study uses monthly data from January 2010 to January 2016 for each variable.

The results of this study indicate that the Nikkei 225 Index variables have a negative effect on JCI. While the world oil price, world gold price, and Dow Jones index have a positive effect on JCI. In addition it was found that the adjusted value of R2 was $88.4 \%$. This means that $88.4 \%$ of JCI movement can be predicted from the movement of the four independent variables.
\end{abstract}

Keywords: JCI, world capital market, macro economic

\section{PENDAHULUN}

Bagi para investor, melalui pasar modal dapat memilih obyek investasi dengan beragam tingkat pengembalian dan tingkat risiko yang dihadapi, sedangkan bagi para penerbit (issuers atau emiten) melalui pasar modal dapat mengumpulkan dana jangka panjang untuk menunjang kelangsungan usaha. Pasar modal diharapkan mampu meningkatkan aktifitas perekonomian, karena pasar modal merupakan alternatif pendanaan jangka panjang bagi perusahaan. Sehingga, perusahaan dapat beroperasi dengan skala yang lebih besar dan pada gilirannya akan meningkatkan pendapatan perusahaan dan kemakmuran masyarakat luas.

Dalam melakukan pemilihan investasi di pasar modal, para investor harus sudah menggunakan pertimbangan yang tidak lepas dari faktor-faktor yang mempengaruhi pasar saham itu sendiri. Saat ini dunia mengalami dampak globalisasi serta revolusi dalam informasi dan teknologi. Karena globalisasi pada gilirannya menimbulkan gejala menyatunya ekonomi semua bangsa yang mengakibatkan suatu negara akan mengalami interdependensi dengan negara lain. Perekonomian dunia dihadapkan dengan runtuhnya 
stabilitas ekonomi global, seiring dengan meluasnya berbagai krisis ke berbagai negara. Dampak globalisasi dibidang ekonomi diikuti oleh adanya liberalisasi dalam bidang perekonomian. Artinya dalam pasar global saat ini, setiap investor dapat berinvestasi dimanapun dia berada (Wondabio, 2006).

Indeks harga saham adalah indikator atau cerminan pergerakan harga saham. Indeks merupakan salah satu pedoman bagi investor untuk melakukan investasi di pasar modal, khususnya saham. Saat ini Bursa Efek Indonesia memiliki 11 jenis indeks harga saham, yang secara terus menerus disebarluaskan melalui media cetak maupun elektronik (www.idx.co.id). Ang (1997) menjelaskan bahwa perubahan harga saham yang diperjualbelikan di bursa efek secara keseluruhan dapat dilihat dari fluktuasi Indeks Harga Saham Gabungan sehingga dapat diketahui apakah pasar dalam keadaan bullish (kuat) atau bearish (lemah). Berfluktuasinya pergerakan indeks dalam industri pasar modal memang sudah seharusnya ditanggapi dengan serius oleh para investor. Banyak faktor yang dapat mempengaruhi Indeks Saham, antara lain perubahan tingkat suku bunga bank sentral, keadaan ekonomi global, harga minyak dunia, harga emas dunia, kestabilan politik suatu negara dan lain-lain (Blanchard, 2017).

Wilayah Asia sebagai wilayah importir minyak neto yang besar tentu saja akan terkena dampak kenaikan harga tersebut. Indonesia merupakan salah satu negara yang membutuhkan energi yang lebih banyak untuk meningkatkan setiap satuan PDB-nya dibandingkan dengan Jepang dan Amerika Serikat. Sehingga harga minyak dunia memegang salah satu peran penting dalam perekonomian Indonesia. Kenaikan harga minyak memiliki efek yang relatif bervariasi pada perekonomian di pasar umum dan khususnya pada pasar modal. Di negara-negara pengekspor minyak, kenaikan harga minyak memiliki dampak positif, namun pada pengimpor minyak dan pengkonsumsi minyak, bahwa kenaikan harga minyak memiliki dampak negatif. Sementara itu, studi empiris dilakukan untuk menilai efek dari perubahan harga minyak dunia pada pasar modal telah dilakukan oleh beberapa peneliti. Diantaranya penelitian yang dilakukan oleh Le dan Chang (2011) menyimpulkan bahwa perubahan harga minyak tidak mempengaruhi pasar saham di Jepang. Penelitian Papież dan Śmiech (2012) menyatakan bahwa tidak ada dampak dari perubahan harga minyak dunia pada indeks S\&P 500. Basit (2013), yang meneliti efek dari perubahan harga minyak dunia pada pasar saham di Pakistan menemukan hasil yang serupa.

Sebaliknya, banyak studi telah menemukan bahwa ada korelasi yang signifikan antara perubahan harga minyak dunia dan pasar saham. Penelitian yang dilakukan oleh Patel (2012); Jubinski dan Lipton (2013); Hussin, et al (2013a); Hussin, et al (2013b) menemukan hasil yang berlawanan. Penelitian Patel (2012) menggunakan pasar modal India sebagai objek penelitian, konsisten dengan temuan tersebut. Dalam penelitian Jubinski dan Lipton (2013) menggunakan indeks S\&P 500, menemukan bahwa perubahan harga minyak dunia memiliki pengaruh yang signifikan terhadap return pasar saham yang diwakili oleh indeks S\&P 500. Penelitian oleh Hussin, et al (2013a) dan Hussin, et al (2013b) juga memperkuat temuan tersebut, mereka menyarankan bahwa perubahan harga minyak memiliki dampak jangka pendek dan jangka panjang pada FTSE Bursa Malaysia Emas Syariah Index (FBMES). Ghorbel, et al (2014) dalam penelitiannya mencoba untuk menjelaskan dampak dari harga minyak, sentimen investor, dan indeks konvensional pada 11 indeks shariah, terutama selama krisis keuangan dan krisis minyak. Bukti empiris menunjukkan bahwa indeks shariah Malaysia dan Indonesia sangat banyak dipengaruhi oleh volatilitas minyak. Hasil estimasi model BEKK-GARCH mengungkapkan bahwa sentimen pesimis investor selama krisis subprime ditransmisikan ke indeks shariah.

Selain minyak, menurut Sunariyah (2011) bahwa emas merupakan salah satu komoditi penting yang dapat mempengaruhi pergerakan bursa saham dan emas 
merupakan salah satu alternatif investasi yang cenderung aman dan bebas resiko. investasi dalam bentuk emas dipercaya sebagai salah satu komoditi yang menguntungkan disebabkan selain harganya yang cenderung mengalami peningkatan, emas juga merupakan bentuk investasi yang sangat liquid, karena dapat diterima di wilayah atau di negara manapun. Emas selalu menjadi investasi yang terpercaya yang menawarkan return keuangan pada investor. Ketika investor berinvestasi di emas berarti mereka telah berinvestasi dalam aset riil (Mulyadi dan Anwar, 2012).

Emas telah didokumentasikan sebagai hedge dan safe haven bagi pasar saham, dalam konteks ini banyak penelitian dengan hasil yang berbeda. Beberapa peneliti menghasilkan mirip dengan karakteristik ini dan beberapa memiliki pendapat sebaliknya untuk peran emas dalam kondisi pasar yang berbeda. Misalnya, Yahyazadehfar dan Babaie (2012) telah menemukan hubungan positif antara emas dan return pasar saham. Sedangkan Ciner, et al (2013) dan Choudhry, et al (2015) menggambarkan bahwa emas memiliki karakteristik, hedge dan safe haven, untuk pasar saham negara maju. Dalam Alaoui, et al (2015) dan Kumar (2014) bahwa hasilnya sama untuk pasar negara berkembang. Baur dan Lucey (2010) memperkenalkan hipotesis hedge dan safe haven. Apakah emas sebagai hedge atau safe haven untuk saham dan menjelaskan bahwa emas adalah yang paling tepat untuk digunakan sebagai hedge untuk rata-rata saham dan safe haven untuk pasar saham selama terjadi gejolak di pasar. Raza, et al (2015) dalam penelitiannya menyelidiki peran aset yang safe haven dan frekuensi yang domain dengan membandingkan return emas dan Indeks Islamic Dow Jones pada pasar negara berkembang di dunia selama dua periode krisis yang berbeda dengan menggunakan data harian dari 1 Januari 1996 sampai 31 Desember 2014. Koherensi Wavelet digunakan untuk memastikan yang terbaik dari frekuensi waktu untuk menentukan kemampuan emas sebagai hedge dan safe haven. Hasilnya menunjukkan bahwa emas mempertahankan kapasitasnya sebagai instrumen hedge untuk BRICS dalam jangka pendek dan jangka panjang selama krisis keuangan Asia 1997-1998 dan pada tahun 2007 krisis keuangan global.

Di sisi lain, Bredin, et al (2014) mempelajari hubungan di pasar negara maju dan melaporkan bahwa emas sebagai hedge dan safe haven tergantung pasar. Sementara, beberapa peneliti telah menentukan hubungan positif antara emas dan return pasar saham. Hood, et al (2013) dan Lucey dan Li (2015) menunjukkan bahwa emas adalah safe haven yang lemah terhadap penurunan pasar saham daripada perak dan indeks volatilitas. Ajmi, et al (2014) menguji hubungan kausal nonlinear antara pasar saham konvensional dan syariah dan reaksi mereka terhadap penularan ekonomi dan keuangan global. Hasilnya menunjukkan bahwa pasar saham syariah tidak terisolasi dari berbagai jenis guncangan eksternal dan sistem keuangan Islam merupakan perlindungan yang lemah terhadap guncangan keuangan yang mempengaruhi pasar saham konvensional dan memiliki diversifikasi portofolio yang kurang. Abbes, et al (2015) meneliti interdependensi yang dinamis di berbagai negara berkembang dan pasar saham syariah negara berkembang dalam periode kekacauan (2002-2007) dan tenang (setelah periode krisis) dan menemukan bahwa indeks saham syariah memiliki manfaat diversifikasi yang potensial dalam jangka pendek dan hal tersebut dapat memperkuat baik untuk pasar negara maju dan berkembang selama periode krisis.

Karim, et al (2009) mengemukakan bahwa pasar modal Indonesia sudah terintegrasi dengan pasar modal dunia. Hal ini menimbulkan konsekuensi bahwa pergerakan pasar modal Indonesia akan dipengaruhi oleh pergerakan pasar modal dunia baik secara langsung maupun tidak langsung (Samsul, 2008). Perekonomian Indonesia sendiri sudah semakin terintegrasi dalam perekonomian global. Perekonomian Indonesia terbuka dari sisi neraca pembayaran mulai dari perdagangan, arus modal masuk dan keluar (capital inflow atau outflow), dan kegiatan pemerintah melalui penarikan dan pembayaran utang luar negeri (www.antaranews.com). Amerika Serikat dan Jepang 
adalah dua negara dengan perekonomian terbesar di dunia (www.kompas.com). Hal ini didasari bahwa pada tahun 2009 nilai gabungan produk domestik bruto kedua negara tersebut mewakili 32,87\% dari total produk domestik bruto seluruh dunia (www.imf.org). Maka jelas bahwa perubahan keadaan ekonomi di kedua negara tersebut dapat mempengaruhi perekonomian Indonesia, baik melalui kegiatan ekspor-impor barang dan jasa, aliran dana dari investor kedua negara tersebut, atau perubahan tingkat risiko bisnis di kedua negara tersebut.

Moldovan dan Medrega (2011) meneliti tentang korelasi pada pasar saham internasional sebelum dan saat terjadinya krisis subprime mortgage di United State (US). Dalam penelitian tersebut terlihat bahwa hubungan antara ketiga indeks yang dipilih yaitu Dow Jones, FTSE, Nikkei 225 justru menjadi lebih kuat selama periode krisis keuangan. Namun, indeks Dow Jones justru berkorelasi negatif dengan Nikkei selama periode krisis, bahkan cenderung lebih rendah daripada periode sebelum krisis. Kizys dan Pierdzioch (2011) yang melakukan penelitian mengenai imbas dari krisis keuangan 2008. Dari penelitian tersebut, ditemukan bahwa krisis subprime mortgage di US memiliki hubungan yang signifikan dengan jatuhnya harga saham konvensional di negara-negara CEE (Central and Eastern Europe). Penelitian ini menggunakan indeks pasar saham dari tiga negara besar CEE yaitu Republik Ceko, Hongaria, dan Polandia serta indeks Jerman, United State (US) dan United Kingdom (UK) sebagai pembanding. Banyak negara yang terkena imbas baik langsung maupun tidak langsung dari krisis yang terjadi di Amerika beberapa saat yang lalu. Disisi lain krisis subprime mortgage di US juga mengakibatkan munculnya penelitian-penelitian mengenai keadaan, efek dan sebab-sebab peristiwa itu terjadi. Dalam penelitian Sampurna (2015) mengenai pasar modal Indonesia dengan pasar modal di kawasan Eropa (UK, Perancis, Jerman, dan Italia). Hasilnya menunjukkan terjadi integrasi antara pasar modal Indonesia dengan Italia begitupun diantara pasar modal dikawasan Eropa. Dimana salah satunya memaparkan tentang adanya efek contagion pada krisis yang terjadi terhadap pasar saham global (Lee, 2012). Efek domino dalam perekonomian dunia akibat krisis finansial AS ini memang merupakan konsekuensi logis dari model perekonomian global yang makin terbuka dan menghapuskan batasan-batasan antar negara. Akibatnya semua pelaku ekonomi dunia rentan terkena dampaknya, terlepas dari fakta bahwa pelaku tersebut ikut menikmati hasil perekonomian tersebut ataupun tidak. Dalam Outlook Ekonomi Indonesia (2009), dijelaskan, krisis keuangan dunia tersebut telah berimbas ke perekonomian Indonesia sebagaimana tercermin dari gejolak di pasar modal dan pasar uang. Indeks Harga Saham (IHSG) pada bulan Desember 2008 ditutup pada level 1.355,4, terpangkas hampir separuhnya dari level pada awal tahun 2008 sebesar 2.627,3, bersamaan dengan jatuhnya nilai kapitalisasi pasar dan penurunan tajam volume perdagangan saham.

Indeks yang akan dijadikan proksi untuk Amerika Serikat adalah Indeks Dow Jones. Indeks Dow Jones merupakan indeks pasar saham tertua di Amerika Serikat dan merupakan representasi dari kinerja industri terpenting di Amerika Serikat (www.nyse.com). Perusahaan yang tercatat di Indeks Dow Jones pada umumnya merupakan perusahaan multinasional. Kegiatan operasi mereka tersebar di seluruh dunia. Perusahaan seperti Coca-Cola, ExxonMobil, Citigroup, Procter \& Gamble adalah salah satu contoh perusahaan yang tercatat di Dow Jones dan beroperasi di Indonesia (www.kompas.com). Perusahaan-perusahaan tersebut pada umumnya beroperasi secara langsung di Indonesia. Sunariyah (2011), menyatakan, Indeks Dow Jones yang bergerak naik, menandakan kinerja perekonomian Amerika Serikat secara umum berada pada posisi yang baik. Dengan kondisi perekonomian yang baik, akan menggerakkan perekonomian Indonesia melalui kegiatan ekspor maupun aliran modal masuk baik investasi langsung maupun melalui pasar modal. Aliran modal yang masuk melalui pasar modal tentu akan memiliki pengaruh terhadap perubahan IHSG. 
Sementara untuk Jepang yang dapat dijadikan proksi adalah Indeks Nikkei 225. Nikkei 225 merupakan indeks bursa saham Tokyo (Tokyo Stock Exchange/TSE), yang sudah sejak tanggal 7 September 1950. Perhitungan indeks ini awalnya dibuat oleh surat kabar harian Nihon Keizai Shimbun (Nikkei) yang dimulai ditahun 1950. Nikkei 225 sering dijadikan bahan acuan di pasar keuangan dan memiliki kesamaan dengan Dow Jones Industrial Average (DJIA). Sejak tahun 1975 hingga 1985 Nikkei kerap disebut Nikkei Dow Jones Stock Average. Indeks Nikkei 225 ini diperkenalkan pada Singapore Exchange ditahun 1986, Osaka Securities Exchange tahun 1988 dan di Chicago Mercantile Exchange ditahun 1990. Saat ini Nikkei 225 Futures sudah diakui sebagai indeks future internasional. Indeks Nikkei sebagai patokan kinerja bursa sahamnya dan terdiri dari berbagai macam perusahaan yang memiliki daerah operasi di Indonesia, diantaranya adalah Mitsubishi Corp, Honda Motor Co Ltd, dan Nikon Corp. Negara Jepang merupakan konsumen nomor satu ekspor material energi seperti minyak bumi dan batu bara yang berasal dari Indonesia. Sehingga adanya fluktuasi pada Indeks Nikkei akan berpengaruh terhadap pergerakan IHSG di BEI

\section{LANDASAN TEORI}

\subsection{Teori Portofolio}

Markowitz (1952), mengemukakan teori portofolio yang dikenal dengan model Markowitz, yaitu memperoleh imbal hasil (return) pada tingkat yang dikehendaki dengan risiko yang paling minimum. Untuk meminimumkan risiko, perlu dilakukan diversifikasi dalam berinvestasi, yaitu membentuk portofolio atau menginvestasikan dana tidak di satu aset saja melainkan ke beberapa aset dengan proporsi dana tertentu.

Kemudian model Markowitz dikembangkan oleh Sharpe (1964), yang dikenal dengan teori keseimbangan pasar modal, bahwa jika seluruh investor dalam berinvestasi melakukan hal yang sama sebagaimana yang dikemukakan oleh Markowitz, maka aset yang diperdagangkan di pasar modal akan habis terbagi dibeli oleh investor, dan proporsi masing-masing surat berharga yang dipegang oleh investor akan identik dengan kapitalisasi aset tersebut di pasar modal.kesimpulannya, portofolio yang efisien dan optimal adalah portofolio pasar itu sendiri. Dengan demikian, investor dalam berinvestasi tidak perlu membentuk portofolio efisien dan optimal sebagaimana dikemukakan Markowitz, melainkan cukup membentuk portofolio yang identik dengan portofolio pasar.

\subsection{Indeks Harga Saham dan Pergerakannya}

Indeks harga saham adalah suatu indikator yang menunjukkan pergerakkan harga saham (www.idx.co.id). Berdasarkan hal tersebut bahwa dengan adanya indeks, maka dapat diketahui apakah trend harga saham saat ini mengalami kenaikan, penurunan atau cenderung stabil.

Indeks harga saham menggambarkan suatu informasi historis mengenai pergerakan saham, sampai pada tanggal tertentu (Sunariyah, 2011). Sunariyah (2011) menjelaskan biasanya pergerakan harga saham tersebut disajikan setiap hari, berdasarkan harga penutupan di bursa pada hari tersebut dan disajikan untuk periode tertentu. Dalam hal ini indeks harga saham mencerminkan suatu nilai yang berfungsi sebagai pengukuran kinerja suatu bursa efek.

Pergerakan indeks menjadi indikator penting bagi para investor untuk menentukan apakah mereka akan menjual, menahan atau membeli suatu atau beberapa saham (Sunariyah, 2011). Hal ini disebabkan harga-harga saham bergerak dalam hitungan detik dan menit, sehingga nilai indeks di suatu bursa dapat mengalami kenaikan atau penurunan dalam hitungan waktu yang cepat pula. 
Menurut Hirschey dan Nofsinger (2008) perubahan indeks harga saham ini sangat dipengaruhi oleh kondisi makro ekonomi suatu negara dan negara lain yang mempengaruhi, dimana kondisi makro ekonomi suatu negara akan membentuk iklim investasi. Perubahan Iklim investasi tersebut yang akan berpengaruh secara langsung pada perubahan indeks harga saham di satu bursa efek.

\subsection{Pengaruh Antara Variabel-Variabel Penelitian}

\subsubsection{Pengaruh Harga Minyak Dunia terhadap IHSG}

Minyak mentah atau crude oil merupakan salah satu energi yang sangat vital. Hal ini dikarenakan hasil olahan minyak mentah merupakan komoditas dan sumber energi utama dunia saat ini. Pertumbuhan indeks yang tinggi di sektor pertambangan menunjukkan minat investor yang besar terhadap saham-saham sektor pertambangan yang dipandang sebagai pilihan investasi yang menguntungkan. Selain itu, investor di pasar modal menganggap bahwa dengan naiknya permintaan minyak secara global merupakan pertanda membaiknya pemulihan ekonomi global paska krisis. Sebaliknya, turunnya permintaan minyak secara global mencerminkan melemahnya pemulihan ekonomi global. Dengan demikian, jika harga minyak dunia meningkat, ekspektasi terhadap membaiknya kinerja perusahaan-perusahaan juga akan meningkat dan otomatis harga sahamnya akan ikut meningkat. Penelitian yang dilakukan oleh Killian dan Park (2009) menunjukkan bahwa harga minyak dunia berpengaruh positif dan signifikan terhadap pasar modal Amerika Serikat. Hal ini didukung oleh penelitian lainnya seperti Patel (2012); Jubinski dan Lipton (2013); Hussin, et al (2013a); Hussin, et al (2013b); dan Ghorbel, et al (2014).

$$
H_{l}=\text { Bahwa Harga Minyak Dunia berpengaruh positif terhadap IHSG. }
$$

\subsubsection{Pengaruh Harga Emas Dunia terhadap IHSG}

Emas telah menjadi logam mulia yang penting selama berabad-abad, dan memainkan peran khusus sebagai hedge terutama dari ketidakpastian politik dan ekonomi (Aggarwal dan Lucey, 2007). Emas merupakan aset pengganti (substitusi) yang sangat penting bagi saham. Oleh sebab itu, kenaikan return emas akan mendorong investor untuk menjual saham mereka dan membeli emas untuk mendapatkan keuntungan yang lebih. Sehingga dapat dikatakan investasi emas dan investasi saham bersifat substitusi antara satu dengan yang lainnya (Hazandeh dan Kiavand, 2012). Harga emas dan pasar saham pada umumnya bergerak dalam arah yang berlawanan. Pada dasarnya, ketika harga emas turun orang menarik investasinya dari emas dan menginvestasikan seluruh dananya di pasar saham yang pada akhirnya akan meningkatkan nilai pasar saham karena investasi bertambah banyak (Ray, 2013). Hal ini didukung oleh penelitiannya Baur dan Lucey (2010); Ciner, et al (2013); Kumar (2014); Alaoui, et al (2015); dan Choudhry, et al (2015).

$$
\mathrm{H}_{2}=\text { Bahwa Harga Emas Dunia berpengaruh negatif terhadap IHSG. }
$$

\subsubsection{Pengaruh Indeks Dow Jones terhadap IHSG}

Sebagai salah satu kekuatan ekonomi terbesar, pengaruh Amerika Serikat sangat besar bagi negara-negara lain, hal ini juga termasuk pengaruh dari perusahaan-perusahaan dan investornya. Sehingga pergerakan Indeks Dow Jones yang merupakan salah satu Indeks dalam NYSE akan berpengaruh pada pergerakan Indeks saham negara-negara lain. Salah satu contoh pada tahun 2008, dimana saat itu krisis mortgage di Amerika Serikat yang akhirnya juga menyeret IHSG turun hingga sebesar 50\%, padahal dampak krisis itu terhadap perekonomian Indonesia relatif kecil (finance.detik.com). Selain itu, Indeks ini 
dapat menggambarkan mengenai bagaimana performa perekonomian di Amerika Serikat. Dengan naiknya Indeks Dow Jones ini berarti kinerja perekonomian Amerika Serikat ikut membaik. Sebagai salah satu negara tujuan ekspor Indonesia, pertumbuhan ekonomi Amerika Serikat dapat mendorong pertumbuhan ekonomi Indonesia melalui kegiatan ekspor maupun aliran modal masuk baik investasi langsung maupun melalui pasar modal (Sunariyah, 2011). Hubungan diantara beberapa pasar modal didukung oleh penelitiannya Moldovan dan Medrega (2011); Kizys dan Pierdzioch (2011); (Lee, 2012); dan Sampurna (2015).

$H_{3}=$ Bahwa Indeks Dow Jones berpengaruh positif terhadap IHSG.

\subsubsection{Pengaruh Indeks Nikkei 225 terhadap IHSG}

Keterkaitan antara Jepang dan Indonesia dapat dikatakan sangat kuat. Hal ini dikarenakan aktivitas perekonomian, terutama dari sisi ekspor. Jepang adalah negara tujuan ekspor terbesar Indonesia. Negara Jepang merupakan konsumen nomor satu ekspor material energi seperti minyak bumi dan batu bara yang berasal dari Indonesia. Selain itu, Perusahaan yang tercatat di Indeks Nikkei 225 merupakan perusahaan besar yang telah beroperasi secara global, termasuk di Indonesia. Dengan naiknya Indeks Nikkei 225 ini berarti kinerja perekonomian Jepang ikut membaik. Sebagai salah satu negara tujuan ekspor Indonesia, pertumbuhan ekonomi Jepang dapat mendorong pertumbuhan ekonomi Indonesia melalui kegiatan ekspor maupun aliran modal masuk baik investasi langsung maupun melalui pasar modal (Sunariyah, 2011). Hubungan diantara beberapa pasar modal didukung oleh penelitiannya Moldovan dan Medrega (2011); Kizys dan Pierdzioch (2011); (Lee, 2012); dan Sampurna (2015).

$\mathrm{H}_{4}=$ Bahwa Indeks Nikkei 225 berpengaruh positif terhadap IHSG.

\section{METODE PENELITIAN}

\subsection{Populasi dan Sampel}

Populasi yang digunakan dalam penelitian ini adalah seluruh data IHSG, Harga Minyak Dunia (berdasarkan standar WTI), Harga Emas Dunia, Indeks Dow Jones, serta Indeks Nikkei 225. Berdasarkan data yang tersedia di internet untuk semua variabel yang digunakan dalam penelitian ini, tersedia data dari tahun 1990 sampai dengan tahun 2016.

Adapun sampel penelitian ini diambil setelah memenuhi beberapa kriteria yang berlaku bagi penerapan definisi operasional variabel. Teknik pengambilan sampel yang digunakan dalam penelitian ini adalah metode purposive sampling, maka jumlah sampel yang digunakan dalam penelitian ini adalah 73 sampel (Januari 2010-Januari 2016). Alasan pemilihan periode tahun yang digunakan adalah untuk mendapatkan hasil yang lebih akurat sesuai dengan keadaan sekarang ini. Pemilihan data bulanan adalah untuk menghindarkan bias yang terjadi akibat kepanikan pasar dalam mereaksi suatu informasi, sehingga dengan penggunaan data bulanan diharapkan dapat memperoleh hasil yang lebih akurat.

\subsection{Metode Analisis}

\subsubsection{Model Penelitian}

Penelitian ini menggunakan metode kuantitatif dengan analisa regresi linier berganda (multiple regression). Adapun Persamaan regresi linier berganda yang dipakai dalam penelitian ini sebagai berikut:

$$
\text { IHSG }_{t}=a+b_{1} \text { OIL }_{t}+\text { b }_{2} \text { GOLD }_{t}+b_{3} \text { DJIA }_{t}+\text { b }_{4}{\text { IIKKEI } 225_{t}}_{t} e
$$
dimana :

$\mathrm{IHSG}_{\mathrm{t}}=$ Indeks Harga Saham Gabungan 


$$
\begin{array}{ll}
\mathrm{a} & =\text { Konstanta } \\
\mathrm{b}_{1}-\mathrm{b}_{4} & =\text { Koefisien regresi dari setiap variabel independen } \\
\text { OIL }_{\mathrm{t}} & =\text { Harga Minyak Dunia } \\
\text { GOLD }_{\mathrm{t}} & =\text { Harga Emas Dunia } \\
\text { DJIA }_{\mathrm{t}} & =\text { Indeks Dow Jones } \\
\text { NIKKEI 225 }_{\mathrm{t}} & =\text { Indeks Nikkei } 225 \\
\mathrm{e} & =\text { error }
\end{array}
$$

\subsubsection{Pengujian Asumsi Klasik}

Sehubungan dengan pemakaian metode OLS, untuk menghasilkan nilai parameter model penduga yang lebih sahih, maka model asumsi klasik harus diuji. Uji asumsi klasik tersebut terdiri dari: Uji normalitas, Uji Multikolinearitas, Uji Heteroskedastisitas, dan Uji Autokorelasi.

\section{ANALISIS DATA DAN PEMBAHASAN}

\subsection{Deskripsi Variabel Penelitian}

Variabel yang digunakan dalam penelitian ini terdiri dari variabel dependen dan variabel independen. Pada penelitian ini yang menjadi variabel dependen adalah IHSG (Y). Variabel independen pada penelitian ini yang mempengaruhi IHSG adalah harga minyak dunia $\left(X_{1}\right)$, harga emas dunia $\left(X_{2}\right)$, DJIA $\left(\mathrm{X}_{3}\right)$, indeks Nikkei $225\left(\mathrm{X}_{4}\right)$. Hasil data statistik deskriptif ditunjukkan pada tabel 4.1:

\section{Tabel 4.1}

Statistik Deskriptif

\begin{tabular}{lrrrrr} 
& N & \multicolumn{1}{c}{ Minimum } & \multicolumn{1}{c}{ Maximum } & \multicolumn{1}{c}{ Mean } & Std. Deviation \\
\hline IHSG & 73 & 2549,00 & 5518,70 & 4238,1562 & 727,78198 \\
CRUDEOIL & 73 & 32,65 & 112,25 & 82,9242 & 20,16471 \\
GOLD & 73 & 1055,65 & 1826,00 & 1375,1171 & 216,52937 \\
DJIA & 73 & 9774,00 & 18132,70 & 14222,8808 & 2572,80686 \\
NIKKEI 225 & 73 & 8434,61 & 20585,24 & 12912,2249 & 3858,85115
\end{tabular}

Sumber: Data diolah.

Pada Tabel 4.1, dengan jumlah pengamatan selama 73 bulan dimulai dari bulan Januari tahun 2010 hingga bulan Januari tahun 2016, dapat dilihat bahwa nilai terendah IHSG adalah 2.549,00 yang terjadi pada bulan Februari tahun 2010, sementara nilai tertinggi IHSG adalah 5.518,70 yang terjadi pada bulan Maret tahun 2015. Nilai rata-rata IHSG adalah sebesar 4.238,16 dengan standar deviasi sebesar 727,78. Dengan nilai standar deviasi yang sangat besar ini menandakan bahwa nilai IHSG berfluktuasi tajam.

Harga minyak dunia yang digunakan dalam penelitian ini adalah harga minyak dunia yang terbentuk di pasar spot minyak Texas WTI. Dari hasil perhitungan pada Tabel 4.1 dapat dilihat bahwa harga rata-rata minyak dunia selama periode pengamatan adalah sebesar $\$ 82,92 /$ barrel, dengan harga tertinggi sebesar \$112,25/barrel yang terjadi pada bulan April tahun 2011, sementara harga 
terendah sebesar $\$ 32,65 /$ barrel yang terjadi pada bulan Januari tahun 2016. Nilai standar deviasi harga minyak dunia adalah sebesar 20,17. Secara umum harga minyak dunia selama periode pengamatan mengalami fluktuasi dari tahun ke tahun.

Data hasil uji statistik deskriptif pada Tabel 4.1 menunjukkan harga rata-rata emas dunia selama periode pengamatan adalah sebesar $\$ 1.375,12$ /troy-ounce dengan harga terendah adalah $\$ 1.055,65 /$ troy-ounce yang terjadi pada bulan November tahun 2011 sementara harga tertinggi adalah \$1.826,00/troy-ounce yang terjadi pada bulan Agustus tahun 2011. Nilai standar deviasi sebesar 2.572,81 menunjukkan bahwa harga emas cenderung berfluktuasi. Selain itu selama periode pengamatan ditemukan bahwa harga emas dunia menunjukkan kecenderungan untuk selalu meningkat.

Pada indeks Dow Jones yang merupakan indeks yang mewakili New York Stock Exchange, dari Tabel 4.1 dapat dilihat bahwa nilai rata-rata Indeks Dow Jones adalah sebesar 14.222,88, dimana nilai terendah adalah sebesar 9.774,00 yang terjadi pada bulan Juni tahun 2010. Sementara nilai tertinggi adalah sebesar 18.132,70 yang terjadi pada bulan Februari tahun 2015. Nilai standar deviasi dari indeks Dow Jones adalah sebesar 1.650,32. Ini menunjukkan bahwa Indeks Dow Jones cenderung berfluktuasi.

Indeks Nikkei 225 dapat dilihat pada Tabel 4.1, dimana nilai rata-rata indeks Nikkei 225 adalah sebesar 12.912,23, dengan nilai terendah adalah 8.434,61 yang terjadi pada bulan November tahun 2011, sedangkan nilai tertinggi adalah sebesar 20.585,24 yang terjadi pada bulan Juli tahun 2015. Nilai standar deviasi dari indeks Nikkei 225 adalah sebesar 3.858,85. Hal ini berarti bahwa selama periode pengamatan, indeks Nikkei 225 berfluktuasi cukup tajam.

\subsection{Uji Asumsi Klasik}

\subsubsection{Uji Normalitas}

Uji normalitas dilakukan untuk menguji apakah dalam sebuah model regresi, residu dari persamaan regresi mempunyai distribusi normal atau tidak. Berikut disajikan hasil dari Kolmogorov-Smirnov test dalam Tabel 4.2

Tabel 4.2

\begin{tabular}{lrrrrr} 
& \multicolumn{2}{c}{ Nilai Kolmogorov-Smirnov Test } & & \\
& DJIA & NIKKEI225 & IHSG & SQKOIL & SQGOLD \\
\hline $\mathrm{N}$ & 73 & 73 & 73 & 73 & 73 \\
Kolmogorov-Smirnov Z & 1,128 & 1,166 &, 583 &, 840 & 1,127 \\
Asymp. Sig. (2-tailed) &, 157 &, 178 &, 886 &, 480 &, 158
\end{tabular}

Dengan melihat hasil dari uji di atas dapat disimpulkan bahwa semua variabel yang digunakan dalam penelitian ini, yaitu IHSG, Harga Minyak Dunia, Harga Emas Dunia, Indeks Dow Jones, dan Indeks Nikkei 225 memiliki tingkat signifikansi diatas 0,05. Artinya data yang digunakan dalam penelitian ini memiliki distribusi yang normal dan menunjukkan bahwa model regresi layak dipakai karena memenuhi asumsi normalitas.

\subsubsection{Uji Autokorelasi}


Uji autokorelasi bertujuan untuk menguji apakah dalam suatu model regresi linear ada korelasi antara kesalahan pengganggu pada periode sekarang dengan periode sebelumnya. Berikut disajikan hasil perhitungan uji autokorelasi dalam tabel 4.3.

\author{
Tabel 4.3 \\ Nilai Durbin-Watson Test \\ Durbin-Watson \\ 1,968 \\ Sumber: Data diolah.
}

Dari hasil di atas terlihat bahwa nilai Durbin Watson adalah sebesar 1,968. Nilai Durbin-Watson berdasarkan tabel dengan derajat kepercayaan sebesar 5\% adalah dl sebesar 1,51 dan du sebesar 1,74, sehingga nilai 4-du adalah 2,26. Nilai Durbin Watson pada penelitian ini adalah 1,968, sehingga berada terletak diantara du dan 4-du, maka model regresi ini menunjukkan tidak adanya autokorelasi dan layak digunakan.

\title{
4.2.3. Uji Multikolinearitas
}

Uji Multikolinearitas bertujuan untuk menguji apakah model regresi ditemukan adanya korelasi antar variable independen. Berikut disajikan hasil perhitungan uji multikoliniearitas pada tabel 4.4.

Tabel 4.4

\begin{tabular}{lcc}
\multicolumn{3}{c}{ Hasil Uji Multikolinearitas } \\
& Tolerance & VIF \\
\hline SQKOIL &, 493 & 2,029 \\
SQGOLD &, 248 & 4,036 \\
DJIA &, 264 & 4,589 \\
NIKKEI225 &, 238 & 3,284
\end{tabular}

Sumber: Data diolah.

Dari hasil uji multikolinearitas diperoleh hasil bahwa semua variabel independen dari model regresi tidak terdapat multikolinearitas yang ditunjukkan oleh nilai VIF yang dibawah 10 dan nilai tolerance yang lebih besar dari 0,1 . Ini menunjukkan bahwa model regresi ini layak untuk digunakan karena tidak terdapat variabel yang mengalami multikolinearitas.

\subsubsection{Uji heterokedastisitas}

Uji heteroskedastisitas bertujuan untuk menguji apakah dalam model regresi terjadi ketidaksamaan variance dari residual satu pengamatan ke pengamatan yang lain. Model yang baik adalah yang homoskedastisitas (Ghozali, 2013).

\section{Gambar 4.1}

Hasil Uji Heterokedastisitas 


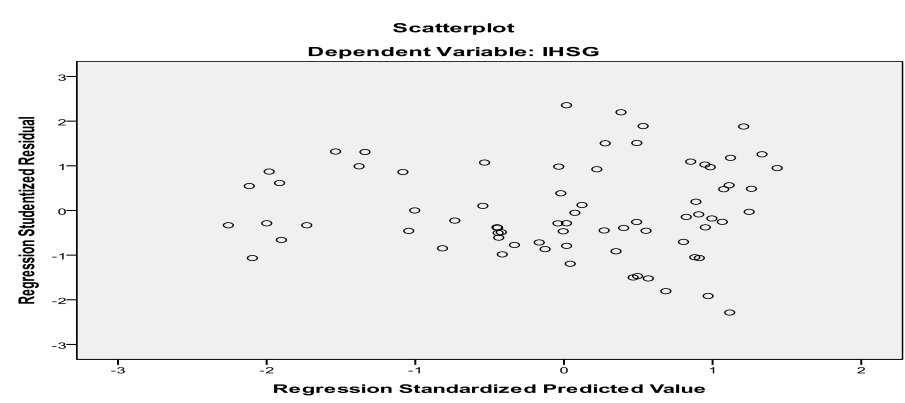

Sumber: Data diolah.

Berdasarkan gambar di atas terlihat bahwa titik-titik yang ada tidak membentuk suatu pola tertentu atau titik-titik yang ada menyebar diatas dan dibawah angka nol sehingga bisa disimpulkan bahwa dalam penelitian ini model regresi yang dipakai tidak mengalami heteroskedastisitas.

\subsection{Uji Hipotesis}

\subsubsection{Koefisien Determinasi}

Koefisien Determinasi $\left(\mathrm{R}^{2}\right)$ mengukur seberapa jauh kemampuan model dalam menerangkan variasi variabel dependen. Dalam perhitungan statistik yang digunakan dalam penelitian ini adalah Adjusted $\mathrm{R}^{2}$. Berikut adalah koefisien determinasi yang disajikan dalam Tabel 4.5.

\section{Tabel 4.5}

\begin{tabular}{ccc}
\multicolumn{3}{c}{ Koefisien Determinasi } \\
$\mathrm{R}$ & $\mathrm{R}^{2}$ & Adjusted $\mathrm{R}^{2}$ \\
\hline$, 944 \quad, 890 \quad, 884$ \\
Sumber: Data diolah.
\end{tabular}

Dari tabel di atas bahwa nilai Adjusted $\mathrm{R}^{2}$ adalah sebesar 0.884 menunjukkan bahwa variasi variabel independen mampu menjelaskan $88.4 \%$ variasi variabel dependen, sedangkan sisanya yaitu sebesar $11.6 \%$ dijelaskan oleh variabel lain diluar variabel independen. Nilai koefisien korelasi (R) sebesar 0,944 menunjukkan bahwa kuat hubungan antara variabel independen terhadap variabel dependen sebesar $94.4 \%$.

\subsubsection{Uji F}

Uji statistik F pada dasarnya menunjukkan apakah semua variabel independent yang dimasukkan dalam model mempunyai pengaruh secara simultan terhadap semua variabel dependen (Ghozali, 2013). Berikut hasil Uji F disajikan dalam Tabel 4.6.

\begin{tabular}{lrrrrr}
\multicolumn{5}{c}{ Tabel 4.6 } & \\
& Hasil Uji F & & \\
& Sum of Squares & \multicolumn{1}{c}{ df } & Mean Square & \multicolumn{1}{c}{ F } & \multicolumn{1}{c}{ Sig. } \\
\hline Regression & 33948991,463 & 4 & 8487247,866 & 137,839 &, 000 \\
Residual & 4187004,197 & 68 & 61573,591 & & \\
Total & 38135995,660 & 72 & & &
\end{tabular}

Sumber: Data diolah. 
Dari hasil perhitungan di atas dapat dilihat bahwa nilai signifikansi adalah sebesar 0,000 dan nilai $\mathrm{F}$ hitung sebesar 137,839. Dasar pengambilan keputusan adalah tingkat signifikansinya sebesar $5 \%$ atau 0,05 . Karena nilai signifikansi lebih kecil dari 0,05 maka menunjukkan adanya pengaruh Harga Minyak Dunia, Harga Emas Dunia, Indeks Dow Jones, dan Indeks Nikkei 225 secara simultan terhadap IHSG.

\subsubsection{Uji t}

Uji statistik t pada dasarnya menunjukkan seberapa jauh pengaruh satu variabel independen secara parsial didalam menerangkan variasi variabel dependen (Ghozali, 2013). Berikut hasil dari Uji t yang disajikan dalam tabel 4.7:

\begin{tabular}{lrrrrr}
\multicolumn{7}{c}{ Tabel 4.7 } \\
Hasil Uji t & & & \\
& \multicolumn{1}{c}{$\begin{array}{c}\text { Unstandardized } \\
\text { Coefficients }\end{array}$} & $\begin{array}{c}\text { Standardized } \\
\text { Coefficients }\end{array}$ & & \\
\cline { 2 - 5 } & \multicolumn{1}{c}{ B } & Std. Error & Beta & \multicolumn{1}{c}{ t } & \multicolumn{1}{c}{ Sig. } \\
\hline (Constant) & $-2834,029$ & 738,250 & & $-3,839$ &, 000 \\
SQKOIL & 8,502 & 2,709 &, 047 & 4,815 &, 008 \\
SQGOLD & 3,835 & 2,366 &, 293 & 3,625 &, 001 \\
DJIA &, 326 &, 045 & 1,151 & 7,256 &, 000 \\
NIKKEI225 &,- 030 &, 039 &,- 158 & $-2,765$ &, 007
\end{tabular}

Sumber: Data diolah.

Berdasarkan tabel di atas dapat disusun persamaan regresi sebagai berikut : IHSG $=-2834,029+8,502$ Oil $+3,835$ Gold + 0,326 Indeks Dow Jones - 0,030 Indeks Nikkei 225

Hasil hipotesis penelitan pengaruh Harga Minyak Dunia, Harga Emas Dunia, Indeks Dow Jones, dan Indeks Nikkei 225 terhadap IHSG secara parsial akan dibahas sebagai berikut :

1. Dari persamaan regresi di atas, koefisien harga minyak menunjukan nilai positif. Dengan mengasumsikan ketiadaan dari variabel-variabel independen lainnya, maka kondisi tersebut menunjukan adanya hubungan positif antara harga minyak dunia dengan IHSG, dimana kenaikan pada harga minyak dunia akan berakibat pada kenaikan angka IHSG. Koefisien regresi variabel harga minyak dunia sebesar 8,502 menunjukan bahwa jika harga minyak dunia mengalami kenaikan sebesar 1 poin, maka IHSG akan mengalami peningkatan sebesar 8,502. Pada Tabel 4.7 dapat dilihat bahwa nilai t-hitung dari harga minyak dunia adalah sebesar 4,815 dengan tingkat signifikansi sebesar 0,008. Karena nilai signifikansi lebih kecil dari $5 \%$ dan nilai t hitung $(4,815)$ lebih besar dari t tabel $(1,96)$ maka variabel harga minyak dunia berpengaruh signifikan terhadap IHSG.

2. Dari persamaan regresi di atas, koefisien harga emas dunia menunjukan nilai positif. Dengan mengasumsikan ketiadaan dari variabel-variabel independen lainnya, maka kondisi tersebut menunjukan adanya hubungan positif antara harga emas dunia dengan IHSG, dimana 
kenaikan pada harga emas dunia akan berakibat pada kenaikan angka IHSG. Koefisien regresi variabel harga emas dunia sebesar 3,835 menunjukan bahwa jika harga emas dunia mengalami kenaikan sebesar 1 poin, maka IHSG akan mengalami peningkatan sebesar 3,835. Pada Tabel 4.7 dapat dilihat bahwa nilai t-hitung dari harga emas dunia adalah sebesar 3,625 dengan tingkat signifikansi sebesar 0,001. Karena nilai signifikansi lebih kecil dari $5 \%$ dan nilai t hitung $(3,625)$ lebih besar dari t tabel $(1,96)$ maka variabel harga emas dunia berpengaruh signifikan terhadap IHSG.

3. Dari persamaan regresi di atas, koefisien indeks Dow Jones menunjukan nilai positif. Dengan mengasumsikan ketiadaan dari variabel-variabel independen lainnya, maka kondisi tersebut menunjukan adanya hubungan positif antara indeks Dow Jones dengan IHSG, dimana kenaikan pada indeks Dow Jones akan berakibat pula pada kenaikan angka IHSG. Koefisien regresi variabel indeks Dow Jones sebesar 0,326 menunjukan bahwa jika indeks Dow Jones mengalami kenaikan sebesar 1 poin, maka IHSG juga akan mengalami peningkatan sebesar 0,326. Pada Tabel 4.7 dapat dilihat bahwa nilai thitung dari indeks Dow Jones adalah sebesar 7,256 dengan tingkat signifikansi sebesar 0,000. Karena nilai signifikansi lebih kecil dari 5\% dan nilai t hitung $(7,256)$ lebih besar dari t tabel $(1,96)$ maka terdapat pengaruh signifikan antara variabel indeks Dow Jones terhadap IHSG.

4. Dari persamaan regresi di atas, koefisien indeks Nikkei 225 menunjukan nilai negatif. Dengan mengasumsikan ketiadaan dari variabel-variabel independen lainnya, maka kondisi tersebut menunjukan adanya hubungan negatif antara indeks Nikkei 225 dengan IHSG, dimana kenaikan pada indeks Nikkei 225 akan berakibat pada penurunan angka IHSG. Koefisien regresi variabel indeks Nikkei 225 sebesar -0,030 menunjukan bahwa jika indeks Nikkei 225 mengalami kenaikan sebesar 1 poin, maka indeks IHSG akan mengalami penurunan sebesar 0,030. Pada Tabel 4.7 dapat dilihat bahwa nilai thitung dari indeks Nikkei 225 adalah sebesar -2,765 dengan tingkat signifikansi sebesar 0,007. Karena nilai signifikansi lebih kecil dari 5\% dan nilai t hitung $(-2,765)$ lebih besar dari t tabel $(1,96)$ maka terdapat pengaruh signifikan antara variabel indeks Nikkei 225 terhadap IHSG.

\subsection{Pembahasan Hasil Penelitian}

\subsubsection{Hipotesis 1}

Hipotesis 1 yang diajukan dalam penelitian ini adalah "Bahwa harga minyak dunia berpengaruh positif terhadap IHSG". Berdasarkan hasil perhitungan diperoleh bahwa hipotesis 1 terbukti. Ini disebabkan karena selama periode pengamatan, kenaikan harga minyak disebabkan bukan karena berkurangnya penawaran, tetapi karena meningkatnya permintaan (www.opec.org). Meningkatnya permintaan terhadap minyak ini disebabkan oleh pertumbuhan ekonomi dunia. Dalam laporan global economic prospect dari bank dunia menyatakan bahwa tingkat pertumbuhan ekonomi dunia tumbuh sebanyak 2,6 persen pada 2014, 3 persen tahun 2015, dan diperkirakan 3,3 persen di tahun 2016 
(www.worlbank.org). Negara-negara berkembang akan tumbuh sekitar 4,4 persen pada $2014,4,8$ persen pada 2015, kemudian menguat ke angka 5,3 persen pada 2016 (www.worlbank.org). Di Indonesia sendiri, sejak tahun 2003-2007 produk domestik bruto senantiasa tumbuh sekitar 4,9\% - 5,3\% (www.bps.go.id). Pertumbuhan PDB Indonesia ini sendiri akan tercermin pada IHSG, karena IHSG merupakan salah satu indikator perekonomian suatu negara (Samsul, 2008).

Hasil penelitian ini didukung oleh penelitian sebelumnya yang dilakukan oleh Killian dan Park (2009) menunjukkan bahwa harga minyak dunia berpengaruh positif dan signifikan terhadap pasar modal Amerika Serikat. Hal ini didukung oleh penelitian lainnya seperti Patel (2012); Jubinski dan Lipton (2013); Hussin, et al (2013a); Hussin, et al (2013b); dan Ghorbel, et al (2014).

\subsubsection{Hipotesis 2}

Hipotesis 2 yang diajukan dalam penelitian ini adalah "Bahwa harga emas dunia berpengaruh negatif terhadap IHSG". Berdasarkan hasil perhitungan diperoleh bahwa hipotesis 1 tidak terbukti. Hasil ini menunjukkan bahwa harga emas dunia memiliki pengaruh yang positif terhadap IHSG. Ini disebabkan selama periode pengamatan perekonomian dunia senantiasa mengalami pertumbuhan tiap tahunnya. Peningkatan pertumbuhan ekonomi ini tentunya akan meningkatkan pendapatan rata-rata masyarakat. Di Indonesia sendiri selama tahun 2010-2015, pendapatan per kapita masyarakat Indonesia mengalami kenaikan antara 6\% $12 \%$ per tahunnya (www.bappenas.go.id). Ini berarti bahwa tingkat kesejahteraan masyarakat Indonesia secara umum meningkat. Peningkatan kesejahteraan ini mengakibatkan masyarakat memiliki kesempatan untuk melakukan diversifikasi investasi untuk mengurangi resiko. Salah satu keunggulan dari berinvestasi pada emas adalah nilainya yang cenderung naik, selain itu pemilik emas dapat dengan mudah menjualnya kapan saja ia membutuhkan dana tanpa mengalami kerugian yang besar.

Hasil penelitian ini mendukung penelitian yang dilakukan oleh Twite (2002) bahwa kenaikan harga emas akan mendorong kenaikan indeks harga saham. Begitupun dengan Yahyazadehfar dan Babaie (2012); Hood, et al (2013); dan Lucey dan Li (2015) telah menemukan bahwa hubungan positif antara emas dan return pasar saham.

\subsubsection{Hipotesis 3}

Hipotesis 3 yang diajukan dalam penelitian ini adalah "Bahwa Indeks Dow Jones berpengaruh positif terhadap IHSG". Berdasarkan hasil perhitungan, diperoleh bahwa hipotesis 3 terbukti. Hasil ini menunjukkan bahwa kenaikan indeks Dow Jones akan mendorong kenaikan IHSG dan menunjukkan bahwa dari dua bursa utama di dunia yang diuji pengaruhnya terhadap IHSG, diperoleh hasil bahwa Indeks Dow Jones yang mempunyai pengaruh paling besar terhadap IHSG. Hal ini dilatarbelakangi karena Amerika Serikat merupakan negara tujuan ekspor utama Indonesia (www.bi.go.id). Sehingga perubahan kondisi perekonomian Amerika Serikat yang akan tercermin di Indeks Dow Jones akan memberikan pengaruh bagi perekonomian Indonesia melalui IHSG. Dan Indeks Dow Jones sendiri merupakan rata-rata indeks saham terbesar di dunia, oleh karena itu 
pergerakan indeks Dow Jones dapat mempengaruhi hampir seluruh indeks saham dunia termasuk IHSG.

Hal ini mengkonfirmasi dan sejalan dengan hasil penelitian yang telah dilakukan oleh beberapa peneliti berkaitan dengan hubungan diantara beberapa pasar modal didukung oleh penelitiannya Moldovan dan Medrega (2011); Kizys dan Pierdzioch (2011); (Lee, 2012); dan Sampurna (2015).

\subsubsection{Hipotesis 4}

Hipotesis 4 yang diajukan dalam penelitian ini adalah "Bahwa Indeks Nikkei 225 berpengaruh positif terhadap IHSG". Berdasarkan hasil perhitungan, diperoleh bahwa hipotesis 4 tidak terbukti. Hasil ini menunjukkan bahwa dengan adanya perbedaan dari periode pengumpulan data akan berakibat pula pada kondisi ekonomi negara Jepang yang berbeda pula. Perbedaan kondisi ini ditunjukan dengan informasi yang dikeluarkan oleh Central Intelligent Agency (CIA) dalam bentuk Word Factbook 2012 yang menjelaskan bahwa ekonomi Jepang sedikit kontras dan mengalami perbedaan dengan beberapa negara besar lainnya, sejak Jepang telah jatuh ke dalam resesi hingga tiga kali sejak 2008. Dimulai dengan penurunan tajam nilai ekspor Jepang pada akhir 2008, kemudian dilanjutkan pada tahun 2011 dengan tekanan ekonomi akibat besaran utang yang mencapai $200 \%$ dari GDP justru disaat negara lainnya termasuk Indonesia sedang mengalami pertumbuhan ekonomi yang cukup tinggi, kemudian dilanjutkan dengan terjadinya gempa besar berkekuatan 9,0 SL dan tsunami, bersamaan dengan laporan bulan Maret 2011 yang menunjukan gangguan besar disektor manufaktur. Hal ini tentunya menyebabkan aliran dana investor berpindah ke negara lainnya, salah satunya di Pasar Modal Indonesia.

\section{SIMPULAN DAN REKOMENDASI}

\subsection{Simpulan}

Berdasarkan hasil analisis dan pembahasan yang telah dikemukakan, dapat diambil beberapa kesimpulan sebagai berikut:

1. Harga minyak dunia berpengaruh positif terhadap IHSG. Kondisi ini menunjukkan bahwa meningkatnya harga minyak dunia akan mengakibatkan peningkatan pada IHSG, begitu pula sebaliknya apabila harga minyak dunia mengalami penurunan akan mengakibatkan penurunan pada IHSG.

2. Harga emas dunia berpengaruh positif terhadap IHSG. Kondisi ini menunjukkan bahwa meningkatnya harga emas dunia akan mengakibatkan peningkatan pada IHSG, begitu pula sebaliknya apabila harga emas dunia mengalami penurunan akan mengakibatkan penurunan pada IHSG.

3. Indeks Dow Jones berpengaruh positif terhadap IHSG. Kondisi ini menunjukkan bahwa meningkatnya indeks Dow Jones akan mengakibatkan peningkatan pada IHSG, begitu pula sebaliknya apabila indeks Dow Jones mengalami penurunan akan mengakibatkan penurunan pada IHSG.

4. Indeks Nikkei 225 berpengaruh negatif terhadap IHSG. Kondisi ini menunjukkan bahwa meningkatnya indeks Nikkei 225 akan 
mengakibatkan penurunan pada IHSG, begitu pula sebaliknya apabila indeks Nikkei 225 mengalami penurunan maka akan mengakibatkan kenaikan pada IHSG.

\subsection{Rekomendasi}

Berdasarkan penelitian yang telah dilakukan, maka terdapat beberapa rekomendasi yang ingin disampaikan, antara lain:

1. Penelitian selanjutnya yang ingin meneliti tentang pengaruh beberapa indeks saham dunia dan indikator ekonomi global terhadap kondisi Pasar Modal Indonesia dapat menambahkan variabel indeks negaranegara Asia Pasific lainnya dan variabel makro ekonomi Indonesia. Mengingat pergerakan IHSG cenderung dipengaruhi oleh saham-saham berkapitalisasi besar, maka pada penelitian selanjutnya dapat menggunakan indeks sektoral ataupun indeks lainnya sebagai variabel independen.

2. Bagi para investor yang berinvestasi di Pasar Modal Indonesia hendaknya memperhatikan pergerakan harga minyak dunia, harga emas dunia, indeks Dow Jones, dan indeks Nikkei 225 sebelum melakukan keputusan investasi. Sebab berdasar perhitungan pada bab IV, diperoleh nilai adjusted $\mathrm{R}^{2}$ adalah sebesar 0.884 , ini berarti bahwa variasi dari variabel independen yang digunakan dalam penelitian ini mampu menjelaskan $88,4 \%$ variasi variabel dependen. Ini berarti pergerakan IHSG dapat diprediksi dari pergerakan keempat variabel independen tersebut.

3. Dari keempat variabel independen yang digunakan dalam penelitian ini, variabel yang memiliki pengaruh paling besar terhadap IHSG adalah variabel harga minyak dunia. Ini dapat dilihat dari koefisien variabel harga minyak dunia yang sudah distandarisasi pada persamaan regresi yang memiliki nilai paling besar dibandingkan variabel lainnya. Hal ini berarti bahwa setiap perubahan harga minyak dunia akan berpengaruh terhadap IHSG. Dari penelitian ini juga dapat disimpulkan bahwa pasar modal Indonesia telah terintegrasi dengan pasar modal dunia. Hal ini dapat dilihat dari persamaan regresi yang menunjukkan bahwa IHSG dipengaruhi oleh Indeks Dow Jones dan Indeks Nikkei 225.

\section{DAFTAR PUSTAKA}

Abbes, M. B. dan Trichilli, Y. 2015. Islamic stock markets and potential diversification benefits. Borsa Istanbul Review, 15(2), 93-105.

Aggarwal, Raj dan Lucey, Brian M. 2007. Psychological barriers in gold prices?. Review of Financial Economics 16, 217-230. 
Ajmi, A. N., Hammoudeh, S., Nguyen, D. K., dan Sarafrazi, S. 2014. How strong are the causal relationships between Islamic stock markets and conventional financial systems? Evidence from linear and nonlinear tests. Journal of International Financial Markets, Institutions and Money, 28, 213-227.

Alaoui, A. O., Dewandaru, G., Rosly, S. A., dan Masih, M. 2015. Linkages and co-movement between international stock market returns: Case of Dow Jones Islamic Dubai Financial Market index. Journal of International Financial Markets, Institutions and Money, 36, 53-70.

Ang, R. 1997. Buku Pintar: Pasar Modal Indonesia, First Edition, Mediasoft Indonesia.

Baur, D. G. dan Lucey, B. M. 2010. Is gold a hedge or a safe haven? An analysis of stocks, bonds and gold. Financial Review, 45(2), 217-229.

Basit, A. 2013. Impactof kse-100 index on oil prices and gold prices in Pakistan. IOSR Journal of Business and Mananagement. 9 (5): 66-69.

Bhunia, Amalendu. 2013. Cointegration And Causal Relationship Among Crude Price, Domestic Gold Price And Financial Variables - An Evidence Of BSE And NSE. Journal of Contemporary Issues in Business Research. Vol. 2, No. $1,1-10$

Blanchard, O. 2017. Macroeconomics. Seventh Edition. New Jersey: Pearson Prentice Hall.

Bredin, D., Conlon, T., dan Potì, V. 2014. Does Gold Glitter in the Long-Run? Gold as a Hedge and Safe Haven Across Time and Investment Horizon. Gold as a Hedge and Safe Haven Across Time and Investment Horizon (August 20, 2014).

Choudhry, T., Hassan, S. S., dan Shabi, S. 2015. Relationship between gold and stock markets during the global financial crisis: Evidence from Nonlinear Causality Tests. International Review of Financial Analysis.

Ciner, C., Gurdgiev, C., dan Lucey, B. M. 2013. Hedges and safe havens: An examination of stocks, bonds, gold, oil and exchange rates. International Review of Financial Analysis, 29, 202-211.

Ghorbel, A., Abdelhedi, M., dan Boujelbene, Y. 2014. Assessing the Impact of Crude Oil Price and Investor Sentiment on Islamic Indices: Subprime Crisis. Journal of African Business, 15(1), 13-24.

Ghozali, I. 2013. Aplikasi Analisis Multivariate dengan Program SPSS. BP Undip Semarang. 
Hasanzadeh, A dan Kianvand, M. 2012. The Impact of Macroeconomic Variables on Stock Prices: The Case of Tehran Stock Exchange. Money and Economy. Vol. 6 No. 2. Pp. 171-190.

Hirschey, Mark dan Nofsinger, John, R. 2008. Investment: Analysis and Behavior. McGraw-Hill, New York: USA.

Hood, M. dan Malik, F. 2013. Is gold the best hedge and a safe haven under changing stock market volatility?. Review of Financial Economics, 22(2), 47-52.

Hussin, M. Y. M., F. Muhammad, S. A. Awang, N. F. Marwan, dan A. A. Razak. 2013a. The dynamic interaction between islamic stock market and strategic commodities. Journal of Islamic Economics, Banking and Finance. 9 (3): 53-68.

Hussin, M. Y. M., F. Muhammad, A. A. Razak, G. P. Tha, dan N. Marwan. 2013b. The link between gold price, oil price and islamic stock market: experience from Malaysia. Journal of Stud. in Social Science. 4 (2): 161182.

Jubinski, D., dan A. F. Lipton. 2013. VIX, Gold, and oil: how do commodities react to financial market volatility. Journal of Accounting and Finance.13 (1): 70-88.

Karim, B. A., Majid, M. S. A. dan Karim, S. A. A. 2009. Financial Integration between Indonesia and Its Major Trading Partners. MPRA Paper No. 17277, posted 15 .

Kilian, Lutz dan Park, Cheolbeom. 2007. The Impact of Oil Prices Shocks on the U.S. Stock Market, International Economic Review. Vol. 50, No. 4.

Kizys, R. dan Pierdzioch, C. 2011. The financial crisis and the stock markets of the CEE countries. Finance a Uver. Volume 61. Issue 2. Pages 153.

Kumar, D. 2014. Return and volatility transmission between gold and stock sectors: Application of portfolio management and hedging effectiveness. IIMB Management Review, 26(1), 5-16.

Le, T. H. dan Chang, Y. 2011. Dynamics between strategic commodities and financial variables. Economics Growth Centre. Working Paper.

Lee, Hsien-Yi. 2012. Contagion in International Stock Markets During the Sub Prime Mortgage Crisis. International Journal of Economics and Financial Issues. Vol. 2, No.1, pp.41-53. 
Lucey, B. M. dan Li, S. 2015. What precious metals act as safe havens, and when? Some US evidence. Applied Economics Letters. 22(1), 35-45.

Markowitz, H. M. 1959. Portfolio Selection: Efficient Diversification of Investments. New York: Jhon Wiley \& Son, Inc.

Moldovan, Ioana dan Medrega, Claudia. 2011. Correlation of International Stock Markets Before and During the Subprime Crisis. The Romanian Economic Journal. Year XIV, no. 40.

Mulyadi, M. S. dan Yunita, A. 2012. Gold Versus Stock Investment: An Econometric Analysis. International Journal of Development and Sustainability. Vol. 1 No. 1. Pp. 1-7.

Napompech, K., Amonsri T., dan Nidpa U. 2010. Factors Influecing Gold Consumption for Savings and Investment By People In Bangkok Metropolitan Area. International Journal of Artsand Sciences. Vol. 3 No. 7. Pp. 508-520.

Papież, M. dan Śmiech, S. 2012. Causality in mean and variance between returns of crude oil and metal prices, agricultural prices and financial market prices. paper read at $30^{\text {th }}$ international conference mathematical methods in economics at Karviná: Silesian University, School of Business Administration.

Patel, S. 2012. The effect of macroeconomic determinants on the performance of the indian stock market. NMIMS Management Review. 22: 117-127.

Ray, Sarbapriya. 2013. Causal Nexus Between Gold Price Movement and Stock Market: Evidence From Indian Stock Market. ECONOMETRICS. Vol. 1 No. 1. Pp. 12-19.

Raza, N., Ibrahimy, A., dan Ali, A. 2015. Gold and Islamic Stocks: A Hedge and Safe Haven Comparison in Time -Grequency domain for BRICS. MPRA Paper No. 69366. Online at https://mpra.ub.uni-muenchen.de/69366/.

Sampurna, D. S. 2015. Financial Integration of Indonesia and EU Stock Markets. International Journal of Applied Business and Economic Research.

Samsul, M. 2008. Pasar Modal dan Manajemen Portofolio. Erlangga, Jakarta.

Sharpe, William, F. 1964. Capital Asset Prices: A Theory of Market Equilibrium under Conditions of Risk. The Journal of Finance. Vol. 19, No. 3, pp. 425442.

Sunariyah. 2011. Pengantar Pengetahuan Pasar Modal Edisi Ke 6. Penerbit UPP STIM YKPN, Yogyakarta. 
Twite, Garry. 2002. Gold Prices, Exchange Rates, Gold Stocks and the Gold Premium, Australian Journal of Management, Volume: 27, pp.123-140.

Wondabio, L. S. 2006. Analisa Hubungan Indeks Harga Saham Gabungan (IHSG) Jakarta (JSX), London (FTSE), Tokyo (Nikkei) dan Singapura (SSI), Pendekatan Model Ekonometri - Autocorrelation Condition Heteroscedasticity (ARCH) / Generalized Autocorrelation Condition Heteroscedasticy (GARCH) dan Vector Autoregression (VAR) - Suatu Studi Empiris tahun 2000 - 2005. Jurnal Simposium Nasional Akuntansi IX. Padang.

www.antaranews.com

www.bappenas.go.id

www.bi.go.id

www.bps.go.id

www.en.wikipedia.org

www.finance.detik.com

www.goldfixing.com

www.idx.co.id

www.imf.org

$\underline{\text { www.kompas.com }}$

www.nyse.com

Www.opec.org

www.useconomy.about.com

$\underline{\text { www.worlbank.org }}$

Yahyazadehfar, Mahmood dan Babaie, Ahmad. 2012. Macroeconomic Variables and Stock Price: New Evidence from Iran. Middle-East Journal of Scientific Research 11 (4): 408-415. 